\title{
Eesti ja vene õppekeelega kooliõpilaste kirjutamisoskus emakeele e-tasemetööde katsetuse tulemuste põhjal
}

\author{
ANNE UUSEN, HELIN PUKSAND \\ Tallinna Ülikool
}

Ülevaade. Artiklis keskendutakse eesti ja vene õppekeelega kooliõpilaste kirjutamisoskuse võrdlusele, lähtudes hindamisaluste väljatöötamisel kirjutamisoskuse laiemast definitsioonist ja analüütilise hindamise mudelist. Kirjaliku suhtluse osakaal järjest suureneb ja asjakohane kirjutamisoskus on aina olulisem. Et teada saada, kas ja kuivõrd tulevad eesti ning vene õppekeelega koolide õpilased elulise situatsiooni sarnases kirjutamisolukorras sõnumite edastamisega toime, mõõdeti katselistes e-tasemetöödes ka kirjutamisoskust. Eesti ja vene koolide õpilaste tulemuste võrdlus annab esmast informatsiooni - eestikeelsele õppele ning e-hindamisele täielikul üleminekul - asjakohaste kirjutamisülesannete koostamiseks. Tulemuste analüüsist selgus, et õpilaste kirjutamisoskusest mitmekülgse tagasiside saamiseks tuleb neis hinnata võimalikult paljusid aspekte. Nii e-kirja kui ka jutustava teksti üldine keskmine sooritusprotsent oli kõrgem vene koolide õpilastel. Mõlema koolitüübi II astme õpilaste e-kirja kirjutamise tulemus oli oluliselt parem kui I astme oma, aga jutustavat teksti kirjutasid vene koolides paremini I astme õpilased. Vene õppekeelega koolide õpilaste üldised kõrgemad tulemused annavad põhjust nentida, et eestikeelsele õppele üleminekuks on õppekeeles kirjutamise oskuse edendamiseks olemas sisend, millele õpetamisel toetuda. 
Võtmesõnad: kirjalik tekstiloome; kirjutamisoskuse komponendid; digitaalne kirjutamisoskus; analüütiline hindamine; tekstipõhine hindamine; eesti keel; vene keel

\section{Sissejuhatus}

Viimased poolteist aastat on tõestanud, et digipööre, sealhulgas üleminek e-tasemetöödele, on Eesti hariduses möödapääsmatu. Sammud selle teostamiseks on tegelikult juba astutud enne koroonaaega.

Euroopa Sotsiaalfondi tegevuse "Kaasaegse ja uuendusliku õppevara arendamine ja kasutuselevõtt" digipöörde programm rahastas keele ja kirjanduse valdkonna e-hindamise süsteemi arendamise projekti, mille raames on endise SA Innove (praeguse Haridus- ja Noorteameti) tellimisel Tartu Ülikooli töörühm koostanud põhikooli I astme eesti ja vene keele emakeelena e-tasemetööde katsetestid, mille esimeses osas tuli (ja tuleb ka edaspidi) ópilastel muuhulgas arvutis kirjutada kaks teksti: jutustus pildiseeria põhjal ja e-kiri. Kirjutamisülesanded olid mõlemas koolitüübis ühesugused, mis võimaldab tulemusi objektiivselt võrrelda.

Keele ja kirjanduse valdkonnas ei ole e-tasemetöö tegemises põhimõtteliselt midagi uut. Alates 2014. aastast on toimunud eesti ja vene keele emakeelena (K1) tasemetöö II kooliastmes e-vormis Eksamiinfosüsteemi (EIS) keskkonnas. Küll ei ole see sisaldanud tervikteksti kirjutamist, mis on aga keeleoskuse ja selle hindamise oluliseks osaks. Põhikooli I astme tasemetööd on seni tehtud paberil ning tekstiloomeoskuse mõõtmist see samuti ei sisalda.

Mõlema kooliastme varasemates tasemetöödes on küll mõned vabade vastustega ülesanded, kus õpilastel tuleb vastuseks kirjutada täislause, lõpetada etteantud algusega lause, kirjeldada või põhjendada midagi oma sõnadega, aga hinnatud on neid ainult teksti mõistmise vaatenurgast lähtuvalt (Tasemetööd). Seetõttu ongi e-tasemetööde katsetamise tulemusi analüüsides vaja esmaselt ja enim pöörata tähelepanu põhikooli I ja II astme õpilaste - sealhulgas eriti kirjutamisosa - tulemustele, et täielikult e-hindamisele üle minnes oleks loodavad 
testid/e-tasemetööd ning ülesanded võimalikult jõukohased ja mõõdaksid üldise keeleoskuse ning kitsamalt tekstiloomeoskuse taset võimalikult objektiivselt ja adekvaatselt. Sellealane info on eespool kirjeldatud asjaolude tõttu puudulik.

Vene keele emakeelena (K1) tasemetööde tulemusi on üldse vähem kajastatud või on neid kajastatud peamiselt venekeelses meedias. See on kahetsusväärne, sest olukorras, kus üha enam räägitakse üldisele eestikeelsele õppele üleminekust, on oluline teada, milline on venekeelse kooli õpilaste emakeeleoskus (sealhulgas kirjutamisoskus) võrreldes eestikeelse kooli õpilaste emakeele- ja/või kirjutamisoskusega. Tulevikus, kui vene keelt emakeelena kasutavad õpilased peavad tõenäoliselt tegema tasemetöö võrdselt eestikeelsete õpilastega ka eesti keeles (nende jaoks K2), on vaja osata arvestada võimalike ohukohtadega, mis võiksid takistada neil seda edukalt sooritada.

Emakeel (K1) on oluliseks aluseks teiste (K2, K3 jne) keelte õppimiseks. See võib aidata õppijatel teiste keelte / õpitavate keelte sisendit klassifitseerida ja tõhustada seeläbi keeleõppevõimet. Emakeeleoskus on üheks oluliseks elemendiks, mis mõjutab teise keele omandamist (Wang 2014; Eslon \& Kaivapalu 2020). Inglise keelt emakeelena ja teise keelena kesktasemel valdajate kirjutamisoskuse erinevate aspektide uuringud on näidanud erinevusi nende kirjalike tekstide vahel (Lee 2011:3-8).

Sellest tekkiski huvi ja vajadus 2019. aasta oktoobris katsetatud põhikooli I ja II astme e-tasemetööde kirjutamisosa üldiste tulemuste põhjal võrrelda eesti- ja venekeelsete koolide õpilaste tekstiloome tulemuste sarnasusi ja erinevusi. See annab ühtlasi võimaluse teha uurimistulemuste põhjal edaspidi mõningaid järeldusi, millele tulevikus tähelepanu pöörata, kui hakatakse mõtlema, kas ja mil moel on I ja II astme e-tasemetöödes edaspidi mõistlik mõõta tekstiloomeoskust eesti keeles nii emakeelena kui ka teise keelena. 


\section{Kirjutamisoskusest ja selle hindamisest}

Selleks, et korraldada võimalikult valiidselt ja asjakohaselt kirjutamisoskuse hindamist, on vaja kõigepealt läbi mõelda ning kirjeldada, kuidas defineerida õpilaste kirjutamisoskust selles kontekstis. Konstrukt, mida hakatakse kavandatavas testis mõõtma, peab andma laiapõhjalise aluse nii keeleoskust mõõta võimaldavate testide arendamiseks ja kasutamiseks kui ka testimise ning/või tulemuste uurimiseks (Bachman 1990: 81; Fulcher \& Davidson 2007: 69). Kõnealuse teema kontekstis on konstruktiks kirjutamisoskus.

\subsection{Kirjutamisoskuse olemus ja komponendid}

Nii esimese kui ka teise keele oskamise näitajana on nõutud muude keelelise suhtluse osaoskuste, nagu rääkimise, kuulamise ja lugemise kõrval ka kirjutamise valdamist (Nation \& Macalister 2021). Kirjutamisoskus on üha tähtsam, sest suhtlemine toimub aina enam just kirjutamise teel. Õpilased vajavad seega efektiivset kirjutamisoskust, et täita oma akadeemilisi vajadusi ja tulevase tööelu nõudeid, samuti selleks, et igapäevaelus vajalikul tasemel toime tulla.

Kirjutamisoskus tähendab oskust kirjutada. Kirjutamise oskust ja selle olemust ning komponente saab niisiis seletada kirjutamise mõistest lähtuvalt ning sellega seonduvalt (Uusen 2006; Uusen \& Puksand 2021). Kirjutamine on lühidalt ja erinevate autorite tõlgendusi kokkuvõtvalt öelduna teabe/sõnumi edastamine või originaalsete ideede väljendamine kirjalikus keeles (Rivers 1981: 294; Uusen 2006). Kirjutamisel on keskne koht isiklike kogemuste ja sotsiaalse identiteedi kujunemisel, ning sageli hinnatakse inimest selle järgi, kuidas ta kirjutamisoskust valdab (Hyland 2009: 2). Eriti koolis on see sageli õpilase edukuse näitajaks (Uusen 2006).

Kirjutamisoskuseks nimetatakse üht keelelistest võimetest, mis võimaldab ideede, tunnete ja argumentide väljendamist lausetesse paigutatud sõnade kaudu. Kirjutamisoskust kasutatakse üksteisega kirjalikus 
vormis suhtlemiseks (Riley \& Reedy 2000: 16). Kirjutamine on igapäevase suhtlemise ja ühiskonnas osalemise oluline vorm, samuti koolis toimetuleku eelduseks. Kirjutamisoskust peetakse samal ajal raskeimaks oskuseks nii emakeele kui ka õppekeele edukal omandamisel (Zemach \& Rumisek 2005: V).

Kirjutamisoskus on üks kahest produktiivsest (midagi tootvast) ehk väljendavast keelelise suhtluse osaoskusest, mis peab saama selgeks keelt kasutades ja õppides, sest kirjutamisoskusel on oluline osa kommunikatiivse ning üldise keelepädevuse saavutamisel. Brown (2000: 31) defineerib keelepädevust kui teadmisi keelesüsteemist: selle grammatikareegleid, sõnavara jne ehk kõiki n-ö keeletükke ja seda, kuidas need vastavalt suhtlemisvajadusele kokku sobivad.

Bachman (1990: 87) jagab keelelise kompetentsuse ehk keelepädevuse (kitsamalt ka kirjutamispädevuse) kaheks: organisatoor(ili)seks (vormiline, korralduslik) ja pragmaatiliseks (sisuline, praktiline) pädevuseks (üldisemalt suhtlemiskompetentsus ehk -pädevus). Organisatoorne pädevus on võime mõista ja koostada korrektseid lauseid, saada aru lause tähendusest ning vormida laused asja- ning eesmärgikohaseks tekstiks. Kirjutamine on seega osa keelepädevusest. Pragmaatiline pädevus on oskus organiseerida keeles kasutada olevaid lingvistilisi ressursse sobivas kontekstis suhtlemiseks ja kasutada neid inimeste, objektide, tunnete ning ideede esitamiseks.

Kirjutamine ei ole lineaarselt edenev protsess: selle jooksul liigutakse tekstis pidevalt edasi-tagasi (Urquhart \& Mclver 2005: 5-6; Harmer 2004: 4-10). Enne lõpliku versiooni valmimist ehk n-ö avaldamist tehakse mitmeid parandusi ning erinevaid versioone (Brown 2001: 336). Kirjutatakse väga paljudel eesmärkidel ja mitmes erinevas vormis (vt täpsemalt Uusen 2006). Lugejad, eesmärk ja olukord määravad ära, milline tekst valmib (Harmer 1988: 4; Templeton 1997: 146). Valmiva teksti liiki ja vormi mõjutab ka kirjutamise vahend (Uusen \& Puksand 2021).

Kirjutamine on erakordselt kompleksne kognitiivne tegevus, mille käigus nõutakse kirjutajalt mitme oskuse samaaegselt demonstreerimist. Kirjutamise protsessi käigus peavad õpilased keskenduma ideede 
valimisele, neil peab olema lai sõnavara, nad peavad olema loovad keele kasutamises ja teadma ortograafiat ning grammatikat (Nunan 1991). Üldiselt nõuab kirjutamine oma mõtete organiseeritult ja kavandatult esitamist hästistruktureeritud viisil (Braine \& Yorozu 1998).

Kirjutamisoskust peetakse kõige raskemaks osaoskuseks võrreldes teiste osaoskustega: eriti teise keele (või teises keeles) õppijatele (Javed jt 2013). On ju isegi emakeele rääkijatel raskusi hea kirjutamisoskuse demonstreerimisega (Johnstone jt 2002). Seetõttu pööravad teise keele õpetajad suurt tähelepanu kirjutamisoskuse õpetamisele, sest see on õpilastele vältimatult vajalik oskus akadeemilise edu saavutamiseks. Kirjutamine toetab ühtlasi õpitava keele grammatiliste struktuuride omandamist, aitab suurendada ning arendada sõnavara, kujundada õpistiile, ja aitab kaasa teiste keeleoskuse osaoskuste arendamisele (lugemine, kuulamine ja rääkimine) (Harmer 1988; Kellogg 2008).

Kokkuvõtvalt saab nende määratluste põhjal öelda, et kirjutamisoskus on kvaliteetse kirjutise loomise keeruline ning kompleksne tegevus, mis koosneb erinevatest etappidest. Kirjutamise ajal on vaja tegeleda ja opereerida paljude asjadega samaaegselt: käekiri, häälikuanalüüs, õigekiri, punktuatsioon, sõnade valik /sõnavara, süntaks, kirjutamise eesmärk, teksti ülesehitus, selgus, rütm, lugejate reaktsioon jne (Holliway \& McCutchen 2004). Ehk siis - kirjutamisoskus sisaldab kõikide nende kirjutamise komponentide valdamist ja kirjutamisoskuse hindamiseks tuleb põhjalikult läbi mõelda, kuidas, mida ning mis eesmärgil hinnatakse.

\subsection{Kirjutamisoskuse hindamine}

Kirjutamisoskuse hindamisjuhiste teoreetiliste aluste ja põhimõtete väljatöötamisel saab lähtuda kirjutamise õpetamise üldistest lähenemistest, milleks on protsessi ja produkti- ehk tootepõhine lähenemine (vt täpsemalt Uusen 2006).

Protsessipõhine lähenemine rõhutab kirjutamise tegevusi, mis viivad õppijad ideede genereerimisest ja andmete kogumisest kuni valmis 
teksti avaldamiseni. Protsessipõhine lähenemine on õppijakeskne ning arvestab õpilaste vajaduste, ootuste, eesmärkide, õppimise stiilide, oskuste ja teadmistega (Durga \& Rao 2018). Kirjutamisoskuse hindamisel on fookuses sel juhul kirjutamise protsess.

Produkti- ehk tulemipõhise lähenemise korral on rõhuasetus kirjutamise lõppeesmärgil ehk kvaliteetse asjakohase teksti valmimisel ja hinnatakse kirjutamise tulemit ehk teksti. Üleriigilistes tasemetöödes ongi mõistlik hinnata õpilase loodud teksti: protsessiga seotud aspekte on e-keskkonna jaoks koostatud kirjutamisülesandesse lisada keerulisem (Giraldo 2020).

Tekstide hindamiseks on mitmeid võimalusi. Üldiselt saab eristada kaudset ja otsest hindamist (Dahl \& Farnan 2000: 111). Kaudse hindamise instrumendiks on mitmesugused testid, etteütlus jms, mida on lihtne koostada, läbi viia ja vastavalt saadud punktide arvule numbriga hinnata, kuid mis mõõdavad peamiselt kirjutamise transkriptsioonilisi oskusi. Sellised testid näitavad õpilaste teadmisi õigekirjast, grammatikast ja lausete struktuurist, ka sõnavara, aga mitte kirjutamise kui teksti loomise kompleksset oskust (Writing Assessment 2014). Teisisõnu, kaudne hindamine mõõdab kirjutamise erinevate komponentide omandamist eraldatuna tekstist.

Otsene hindamine hindab kirjutamise tulemit ehk teksti ja annab teavet selle kohta, mida õpilased teevad hästi ja millistele raskustele tuleb klassis tähelepanu suunata. Kõige sagedamini kasutatakse kolme otsese hindamise liiki: peamiste iseloomulike joonte hindamine, holistiline ja analüütiline hindamine (Brindley 2013).

Iseloomulike joonte hindamine on otstarbekas siis, kui on vaja anda hinnang ühe heale kirjutisele iseloomuliku üldise aspekti kohta, näiteks teemakohasus, tekstiliigile vastavus, või kui on tegemist algajate kirjutajatega ja on vaja tagasisidet, kas kirjutamise peamine eesmärk on täidetud (Dahl \& Farnan 2000: 111)

Holistiline hindamine annab kirjutisele hinnangu üldmulje põhjal. See tähendab, et õpilane saab oma töö eest ühe hinde. Iga hinde jaoks on reeglina koostatud kirjeldus, millistele kriteeriumitele peab kirjutis 
selle hinde saamiseks vastama. Kõige kõrgem hinne tähendab, et kirjutis on väga kõrgekvaliteediline ja madalam hinne, et kirjutis on mingis osas madalama kvaliteediga, mis ei anna aga kirjutajale mingit sisulist ega konkreetsemat informatsiooni, mis on tal hästi ja mida tuleb veel oppida. Ühe hindega hindamine on otstarbekas siis, kui on vaja anda üldine hinnang õpilas(t)e kirjutamisoskusele (meil Eestis hinnatakse õpilaste kirjutisi enamasti just ühe hindega). Õppetöö planeerimiseks ja kirjutamisoskuse edendamiseks ei ole aga sellest palju abi ei õpetajal ega õpilasel (Singer \& LeMahieu 2011).

Analüütiline hindamine arvestab mitmeid efektiivsele kirjutamisele iseloomulikke tunnuseid või komponente (vt ptk 1.1). Kõigist kolmest nimetatud otsese hindamise liigist annab analüütiline hindamine kirjutaja kirjutamisoskuse ja kirjutise kvaliteedi kohta kõige rohkem informatsiooni (Brindley 2013).

Komponendid, mida kirjutistes hinnata, on erinevate uurijate poolt leitud pärast tuhandete tööde läbilugemist lähtuvalt sellest, millised leiti olevat otseselt teksti kvaliteedi näitajad (Moskal 2003). Spandel ja Stiggins (1997) pakkusid esimestena välja seitse iseloomulikku joont või tunnust (ingl traits), mis iseloomustavad efektiivset kirjutamist/teksti: sisu (ideas), struktuur (organisation), sõnum (voice), sõnavara (word choice), lausestus (sentence fluency), kokkulepped (conventions; sisaldab muuhulgas ka õigekirja, punktuatsiooni ja grammatikat) ja esitus (prsesentation: käekiri, paigutus, kujundus) (McMackin \& Siegel 2002; Tierney \& Simon 2004). Hindamise analüütiline mudel annab järelikult õpetamise parendamise ja diferentseerimise ning õpilastele võimlikult infomahuka tagasiside andmise seisukohast kõige objektiivsemat teavet, sest paljusid kirjutamise komponente hinnatakse eraldi.

Analüütilist hindamist aja jooksul praktiseerides ja täiendades on leitud, et alati ei pea hindama kõiki komponente: mõnikord kasutatakse nelja, mõnikord kolme või viit jne. Samuti on võimalik komponente liita suuremateks sisulisteks plokkideks, sõltuvalt vajadusest ja hindamise eesmärgist ehk sellest, millist informatsiooni tahetakse õpilaste kirjutamisoskuse kohta saada (Brindlay 2013). 
EESTI JA VENE ÕPPEKEELEGA KOOLIÕPILASTE KIRJUTAMISOSKUS ...

Kõike seda arvestades on katselistes e-tasemetöödes tuginetud õpilaste kirjutamisoskuse hindamisel just analüütilise hindamise põhimõttele.

\section{Materjal ja meetod}

Õpilaste kirjutamisoskuse hindamiseks kasutati katseliste e-tasemetööde tekstiloomeülesandeid. Mõlemas kooliastmes oli nii eesti kui ka vene keeles kaks kirjutamisülesannet: kirjaliku suhtluse ja jutustava teksti kirjutamise ülesanne. I kooliastme õpilased pidid kirjaliku suhtluse ülesandes kirjutama e-kirja sõbrale, et kutsuda sõber AHHAAkeskuse limonaadi tegemise töötuppa. II astmes tuli õpilastel kirjutada e-kiri raamatukogutöötajale, et paluda raamatu tähtaja pikendust ja uurida, kui palju maksab raamatukaanest koopia tegemine. Teises ülesandes oli mõlema kooliastme õpilastele ette antud 4-pildiline pildiseeria, mille põhjal pidid õpilased kirjutama jutustava teksti. I kooliastmes oli teksti eeldatav pikkus umbes 70 sõna, II kooliastmes 100 sõna. Mõlemas kooliastmes ja keeles kasutati sama pildiseeriat, kuid II kooliastme ülesanne oli keerukam: õpilased pidid piltide põhjal järeldama, kuidas võiks lugu edasi minna. Ülesanded olid eelnevalt ühe-kahe klassiga testitud. Pärast eeltestimist täiendati tööjuhendeid: lisati eeldatav sõnade arv, kuna eeltestimisel olid tekstid väga erineva pikkusega (I kooliastmes tekstide pikkus 4-149 sõna, II astmes 27-677 sõna).

Kõik õpilased tegid e-tasemetöid eksamiinfosüsteemis EIS. Oluline on teada, et selles süsteemis ei saanud õpilased kasutada õigekirjakorrektorit. Kahe teksti kirjutamiseks oli mõlemas kooliastmes aega kokku 60 minutit. Eesti õppekeelega koolis osales katsetusel I kooliastmes 6 koolist 249 õpilast (3.-4. klassist), kellest 50,6\% olid poisid ja 49,4\% tüdrukud. II kooliastmes kirjutas e-tasemetööd 20 eesti õppekeelega koolist 251 õpilast (6.-7. klassist), kellest 55,8\% olid poisid ja 44,2\% tüdrukud. Vene õppekeelega koolis osales katsetuses I kooliastmes 5 koolist 126 õpilast (3.-4. klassist), kellest poisse oli 57,1\% ja tüdrukuid 42,9\%. II kooliastmes katsetas testi 4 vene õppekeelega koolist 131 õpilast 
(6.-7. klassist): neist 53,4\% olid poisid ja 46,6\% tüdrukud. Vene õppekeelega koole oli katsetuseks raskem leida kui eesti õppekeelega koole.

Mõlemas koolitüübis hindas kõiki ülesandeid kaks hindajat hindamisjuhendi järgi, mis oli mõlemas astmes ja keeles ühesugune (venekeelsete koolide õpetajate jaoks tõlgiti hindamisjuhend vene keelde), kuid hindamisel pidid hindajad lähtuma vastava kooliastme õpitulemustest. Kuna taseme- ja eksamitööde e-hindamise arendus ei ole veel lõppenud ning e-hindamisele ülemineku ajakava pole avalik, siis ei saa hindamisjuhendi ja oskustasemete kirjeldusi/detaile artiklis avaldada.

Mõlemas tekstiloomeülesandes hinnati kolme aspekti: teksti- ehk sisuloome, õigekeelsuse ja digitaalse kirjutamise oskust, kirjaliku suhtluse ülesandes lisaks kirjaliku suhtluse oskust. Tekstiloome aspekti all analüüsiti, kas tekst vastab ülesande eesmärgile, kas tekst on terviklik ja sidus ning missugune on õpilase sõnavara. Õigekeelsuse hindamisel lähtuti kummagi õppekeele puhul vastava kooliastme õpitulemustest, mis on kirjeldatud põhikooli riiklikus õppekavas (PRÕK 2011). Digitaalse kirjutamise oskuse all hinnati õpilase trükitehnilisi oskusi: kas ja kui palju teeb õpilane hooletus- ja trükivigu ning kas järgib vormistusreegleid. Kirjaliku suhtluse hindamisel jälgiti, kas tekstis antakse edasi vajalik info ja arvestatakse suhtluspartneriga. Enne hindamist läbisid kõik hindajad koolituse ja hindamise ajal said vajadusel nõu hindamisjuhilt.

Kirjutamisülesannete analüüsimiseks kasutati ülesannete keskmist tulemust, ülesande korrelatsiooni tasemetöö kogutulemusega (Rit), ülesande korrelatsiooni ülejäänud ülesannete kogutulemusega (Rir) ja Cronbachi alfat. Cronbachi alfaga mõõdeti ülesannete reliaablust.

\section{I ja II kooliastme õpilaste kirjutamise oskus}

Siinses peatükis esitleme tulemusi esmalt ülesannete kogutulemuste ja seejärel kirjutamisoskuse erinevate aspektide kaupa. 


\subsection{Eesti ja vene kooli õpilaste kirjutamisoskus}

Kõigepealt kontrollisime, kas ülesanded mõõtsid seda, mida taheti mõõta. Kirjutamisülesannete sisemine reliaablus oli suur (Cronbachi alfa oli üle 0,7) viiel ülesandel: eestikeelses tasemetöös I astme kirjaliku suhtluse ülesandel (Cronbachi alfa oli 0,76) ja II astme mõlemal ülesandel (Cronbachi alfa oli vastavalt 0,79 ja 0,74 ) ning venekeelses tasemetöös nii I kui ka II astme kirjaliku suhtluse ülesandel (Cronbachi alfa oli vastavalt 0,82 ja 0,7$)$. Eestikeelse tasemetöö I astme ja venekeelse mõlema astme jutustava teksti kirjutamise ülesannete reliaablus jäi alla 0,7: eesti I astme ülesandel oli Cronbachi alfa 0,68, vene I astme ülesandel 0,54 ja II astmel 0,51. Madalat reliaablust saab seletada hinnatavate aspektide vähesusega. Jutustava teksti kirjutamise ja kirjaliku suhtluse ülesande omavaheline korrelatsioon oli eesti e-tasemetöös I kooliastmes 0,48 ja II kooliastmes 0,62 ning vene e-tasemetöös I astmes 0,47 ja II astmes 0,55, mis näitab, et II kooliastmes mõõtsid kirjutamisülesanded samasuguseid oskusi paremini kui I kooliastmes. Tulemustest võib järeldada, et ülesanded olid usaldusväärsed ja mõõtsid seda, mida eeldati. Ülesannete korrelatsioon tasemetöö kogutulemusega (Rit) on võrdlemisi tugev (vt tabel 1), jäädes vahemikku 0,46-0,78. Korrelatsioonikordaja Rir, mis näitab ülesannete eristusjõudu, jääb vahemikku 0,38-0,68.

Kirjutamisülesannete tulemused on esitatud tabelis 1. Kirjaliku suhtluse ehk e-kirja kirjutamise ülesande (ülesanne 1) sooritasid ootuspäraselt paremini II kooliastme õpilased - keskmine sooritusprotsent oli II astme eesti õpilastel 70\% ja vene õpilastel 73\%, I astme eesti õpilastel aga $61 \%$ ja vene õpilastel $67 \%$. Venekeelsete õpilaste sooritus oli veidi parem kui eestikeelsete oma. Jutustava teksti kirjutamisel (ülesanne 2) aga eesti koolis õppeastmeti erinevusi ei ilmnenud, sest nii I kui ka II kooliastme eesti õpilaste keskmine sooritusprotsent oli 53\%. Vene koolis oli jutustava teksti sooritusprotsent aga I kooliastmel pisut parem (vrd I aste $65 \%$ vs. II aste 62\%). Ka jutustavat teksti kirjutasid vene õppekeelega kooli õpilased paremini. 
TABEL 1. Kirjutamisülesannete tulemused

\begin{tabular}{|c|c|c|c|c|c|c|c|}
\hline & Min & $\begin{array}{c}\text { Keskmine } \\
\text { tulemus }\end{array}$ & Keskmine & $\operatorname{Max}$ & $\begin{array}{c}\text { St. } \\
\text { hälve }\end{array}$ & Rit & Rir \\
\hline \multicolumn{8}{|c|}{ eesti } \\
\hline \multicolumn{8}{|c|}{ I kooliaste } \\
\hline ül 1 & 0 & 9,82 & $61 \%$ & 15,5 & 2,7 & 0,59 & 0,44 \\
\hline ül 2 & 0 & 6,37 & $53 \%$ & 12 & 2,0 & 0,62 & 0,51 \\
\hline \multicolumn{8}{|c|}{ II kooliaste } \\
\hline ül 1 & 0 & 11,25 & $70 \%$ & 16 & 2,8 & 0,78 & 0,68 \\
\hline ül 2 & 2 & 6,32 & $53 \%$ & 12 & 1,9 & 0,72 & 0,64 \\
\hline \multicolumn{8}{|c|}{ vene } \\
\hline \multicolumn{8}{|c|}{ I kooliaste } \\
\hline ül 1 & 0 & 10,7 & $67 \%$ & 16 & 2,9 & 0,56 & 0,41 \\
\hline ül 2 & 2 & 7,75 & $65 \%$ & 11 & 1,7 & 0,63 & 0,55 \\
\hline \multicolumn{8}{|c|}{ II kooliaste } \\
\hline ül 1 & 6,5 & 11,66 & $73 \%$ & 15,5 & 2,1 & 0,52 & 0,41 \\
\hline ül 2 & 4 & 7,47 & $62 \%$ & 11,5 & 1,7 & 0,46 & 0,38 \\
\hline
\end{tabular}

Soolises võrdluses oli tüdrukute sooritus parem kui poiste oma mõlemas kooliastmes ja mõlemas keeles nii kirjaliku suhtluse kui ka jutustava teksti kirjutamise ülesandes (vt tabel 2).

Kirjaliku suhtluse ülesandes oli I kooliastmes eesti tüdrukute keskmine tulemus $64,2 \%$ ja poistel $58,5 \%$, vene tüdrukutel $71,4 \%$ ja poistel $63,2 \%$, II kooliastmes eesti ópilastel vastavalt $75,7 \%$ ja $66 \%$ ning vene ópilastel 78,6\% ja 67,9\%. Jutustava teksti kirjutamisel saavutasid I kooliastmes eesti õppekeelega tüdrukud keskmiselt $57,3 \%$ ja poisid $48,7 \%$ maksimumist, II kooliastmes oli tüdrukute keskmine tulemus 58,6\% ja poistel $47,9 \%$. 


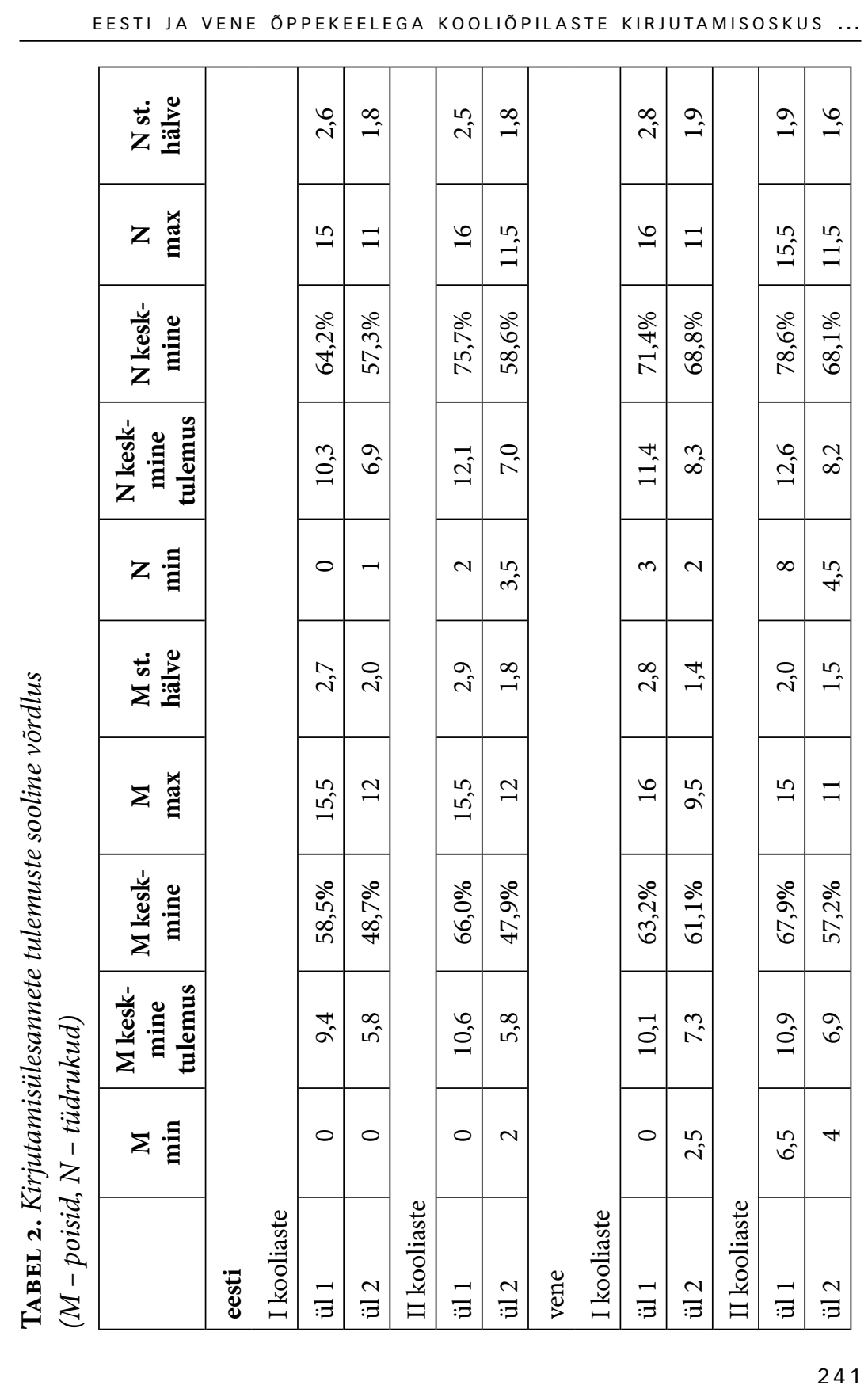




\subsection{Kirjutamisoskuse eri aspektid}

Kirjutamisoskus sisaldab erinevaid aspekte, mistõttu võrdlesime järgnevalt õpilaste tulemusi erinevate kirjutamisaspektide põhjal (vt tabel 3).

TABEL 3. Oppilaste tulemused kirjutamisaspektide kaupa

\begin{tabular}{|l|c|c|c|c|}
\hline Kirjutamisaspekt & eesti I & eesti II & vene I & vene II \\
\hline 1. ül sisu & $56 \%$ & $61 \%$ & $68 \%$ & $75 \%$ \\
\hline 2. ül sisu & $53 \%$ & $57 \%$ & $62 \%$ & $65 \%$ \\
\hline 1. ül õigekeelsus & $71 \%$ & $75 \%$ & $76 \%$ & $80 \%$ \\
\hline 2. ül õigekeelsus & $50 \%$ & $44 \%$ & $72 \%$ & $57 \%$ \\
\hline 1. ül digitaalne kirjutamine & $56 \%$ & $70 \%$ & $62 \%$ & $67 \%$ \\
\hline 2. ül digitaalne kirjutamine & $58 \%$ & $57 \%$ & $60 \%$ & $65 \%$ \\
\hline 1. ül kirjalik suhtlus & $63 \%$ & $75 \%$ & $64 \%$ & $70 \%$ \\
\hline
\end{tabular}

Tekstiloomeülesannetes on kõige olulisem loodava teksti sisu, mis näitab, kuidas on õpilane ülesande juhendist aru saanud, kas ta suudab luua tervikliku ja sidusa teksti ning missugune on õpilase sõnavara. Sisu poolest olid mõlemas keeles ja kooliastmes paremad kirjaliku suhtluse ülesande vastused: eesti õpilastel I kooliastmes 56\% ja 53\% ning II kooliastmes $61 \%$ ja $57 \%$, vene õpilastel I kooliastmes $68 \%$ ja $62 \%$ ning II kooliastmes $75 \%$ ja $65 \%$. Silma jääb, et vene õpilaste tekstiloomeoskust hinnati kõrgemalt kui eesti õpilaste oma. Selle erinevuse põhjus vajab edasisi uuringuid: kas vene õpilased loovad parema sisuga tekste kui eesti õpilased või tekkis erinevus eri hindajate kasutamisest.

Õigekeelsuse aspekt oli mõlemas keeles ja mõlemal kooliastmel kõrgem kirjaliku suhtluse ülesandes: eesti õpilastel I astmes vastavalt 71\% ja 50\%, II astmes 75\% ja $44 \%$ ning vene õpilastel I astmes $76 \%$ ja $72 \%$ ning II astmes $80 \%$ ja $57 \%$. Pildiseeria järgi kirjutatud jutustav tekst oli pikem kui e-kiri, mistõttu võis teksti pikkus mõjutada vigade arvu. Ka varasemad uuringud (vt nt Uusen 2006; Uusen \& Puksand 2021) näitavad, et õpilased teevad pikemas tekstis rohkem vigu. Lisaks näitavad tulemused, 
et II kooliastme õpilaste õigekeelsuse tulemused on jutustava teksti kirjutamisel madalamad kui I kooliastme õpilastel. Seda võib samuti seletada tekstide erinev pikkus, aga ka hindamine: õigekeelsuse hindamisel lähtusid hindajad kooliastmes õpitust - veaks ei loetud neid keelendeid, mille teemasid või reegleid ei ole vastavas kooliastmes veel käsitletud.

Goldberg jt (2003) ning Graham jt (2012) on välja toonud, et arvutis kirjutatud teksti kvaliteet sõltub arvuti kasutamise oskusest. Seetõttu oli üheks hinnatavaks aspektiks digitaalse kirjutamise oskus. I kooliastme sooritus oli nii eesti kui ka vene õpilastel mõlema teksti puhul suhteliselt sarnane: e-kirja ülesandes oli eesti õpilaste digitaalse kirjutamise oskuse keskmine tulemus $56 \%$ ja jutustava teksti ülesandes $58 \%$ ning vene õpilastel vastavalt $62 \%$ ja $60 \%$. Samuti ei ilmnenud suurt erinevust vene II kooliastme õpilaste tulemustes (digitaalse kirjutamise sooritus vastavalt $67 \%$ ja $65 \%$ ). Eesti II astme õpilastel oli aga kirjaliku suhtluse ülesandes digitaalse kirjutamise oskuse aspekt oluliselt kõrgem kui jutustava teksti ülesandes, vastavalt 70\% ja 57\%. Viimane võis olla tingitud tekstide erinevast pikkusest, kuid see ei seleta teiste võrdlusrühmade sarnast tulemust. Hindajad tõdesid, et õigekeelsuse ja digitaalse kirjutamise vigu oli kohati keeruline eristada, kuna raske oli vahet teha, kas näiteks puuduv või ülearune täht viitas trükkimise veale või ei teadnud õpilane, kuidas sõna õigesti kirjutada.

E-kirja ülesandes hinnati ka kirjaliku suhtluse oskust. Selles aspektis ilmnes suur erinevus kooliastmete vahel: I kooliastmes oli kirjaliku suhtluse tulemus eesti ópilastel keskmiselt $63 \%$ ja vene õpilastel $64 \%$, II kooliastmes aga eesti õpilastel 75\% ja vene õpilastel 70\%. Sellega võib seletada erinevust, miks kirjaliku suhtluse ülesande keskmine kogutulemus oli II kooliastmes oluliselt parem kui I astmes. I kooliastme ópilased ei ole arvatavasti puutunud e-kirjade kirjutamisega nii palju kokku kui II kooliastme õpilased, kuna e-kirja kirjutamine on kohustuslik teema II kooliastme ainekavas (PRÕK 2011). 


\section{Kokkuvõte ja järeldused}

Covid-19 pandeemia on oluliselt muutnud mõndagi nii ühiskonnas kui ka koolis. Suhtlemine toimub üha enam hübriidvormis ja seetõttu on enda mõtete suhtluspartnerile kirjalikult arusaadavalt edastamine ehk asjakohane kirjutamisoskus aina olulisem. Nii ema- kui ka võõrkeele hea valdamise enesestmõistetavaks näitajaks on seega muude osaoskuste hulgas kirjutamisoskus tasemel, mis võimaldab olla edukas hariduse omandamisel ja ühiskonnas toimimises.

Uuringud on näidanud, et emakeeleoskus, kitsamalt emakeeles kirjutamise oskus, annab sisendi ja on abiks teise keele ja/või õppekeele omandamiseks. Eestikeelsele õppele täielikult üleminekuks valmistudes on järelikult tähtis teada, mille poolest sarnaneb ja erineb praeguste eesti ja vene õppekeelega koolide põhikooli I ja II astmes õppivate õpilaste kirjutamisoskus. Seni oli seda keeruline teha, sest paberversioonis tasemetööd ei sisaldanud tekstiloome osa ega ühesuguseid ülesandeid. Korraliku ülevaate kirjutiste hindamise võimalustest annab emeriitprofessor Krista Kerge juhitud projekt "Kirjutamise loomulikkuse mudel ja hindamine" (1.1.2011-31.12.2014), millega püüti kaasa aidata eesti keele kui emakeele ja teise keele testide kirjutamisosa ülesannete ja hindamise kvaliteedi tõstmisele. Hinnatavad tekstid olid aga samuti paberil ja eesti ning vene emakeelega õpilaste tulemusi on esialgu analüüsitud vaid põgusalt.

Huvi, vajadus ja võimalus veidi täpsemalt võrrelda kahe koolitüübi õpilaste kirjutamisoskust tekkis põhikooli I ja II astme 2019. aasta oktoobris katsetatud e-tasemetööde kirjutamisosa üldiste tulemuste põhjal. Saadud informatsioon annab muuhulgas võimaluse teha uurimistulemuste põhjal edaspidiseks e-hindamise arenduseks mõningaid järeldusi, millele tulevikus tähelepanu pöörata, kui hakatakse kavandama, kuidas on I ja II astme e-tasemetöödes edaspidi mõistlik nii eesti keele emakeelena kui ka teise keelena tekstiloomeoskust mõõta.

Hinnatava konstrukti määratlemiseks võeti aluseks mitmete autorite definitsioonid, mille kokkuvõtteks saab kirjutamisoskust sõnastada kui kvaliteetse kirjutise loomise keerulist ning kompleksset tegevust, mis 
koosneb erinevatest etappidest. Kirjutamise ajal on kirjutajal vaja tegeleda ja opereerida paljude asjadega samaaegselt ning kirjutamisoskus sisaldab kõikide nende kirjutamise komponentide valdamist. Kirjutamisoskuse hindamiseks peab olema eelnevalt sätestatud, kuidas, mida ning mis eesmärgil hinnatakse. Et e-tasemetöödes saab hinnata kirjutamise tulemit ehk teksti, lähtuti hindamisjuhendi koostamisel produktipõhisest lähenemisest ja kitsamalt analüütilise hindamise mudelist.

Mõlemas kooliastmes oli nii eesti kui ka vene keeles kaks kirjutamisülesannet: kirjaliku suhtluse ja jutustava teksti kirjutamise ülesanne. Analüüs näitas, et ülesanded olid üldiselt usaldusväärsed ja mõõtsid seda, mida eeldati. Jutustava teksti kirjutamise ülesannete reliaablus oli eestikeelse tasemetöö I astmes ja venekeelses mõlemas astmes pigem madal. See näitab, et vähemalt jutustavas tekstis tuleks hinnata võimalikult paljusid aspekte (vt täpsemalt ptk 1.2). Mõlemas tekstiloomeülesandes hinnati kolme aspekti: teksti- ehk sisuloome, õigekeelsuse ja digitaalse kirjutamise oskust ning kirjaliku suhtluse ülesandes lisaks kirjaliku suhtluse oskust.

Eesti ja vene õppekeelega koolide õpilaste tulemuste analüüsist selgus kokkuvõtvalt mõnevõrra üllatuslikult, et nii e-kirja kui ka jutustava teksti keskmised tulemused olid mõlemas astmes paremad vene koolide õpilastel. Üllatuslikult seetõttu, et näiteks PISA uuringutes olid lugemisoskuses just vene koolide õpilaste tulemused kehvemad (Puksand 2019). Et tekste hindasid õpetajad, mitte arvuti, siis võib kõnealust tulemust põhjendada ühest küljest sellega, et inimese hinnang on alati mõjutatud subjektiivsetest faktorites, ükskõik kui üheselt mõistetav on hindamisjuhend.

Teisalt võimaldab see tuleviku vaates kindlamalt arvata, et eestikeelsele haridusele üleminekuks on vene emakeelega põhikooli I ja II astme õpilastel vähemalt kirjutamisoskuse näol rahuldaval tasemel sisend olemas. Tõenduspõhiste järelduste tegemiseks peaks edaspidi täpsemalt uurima õpilaste tekste ka selliste teksti kvaliteedi näitajate osas, mida on võimalik arvutil hinnata: näiteks sõnarikkus, süntaksiga seonduvad näitajad, leksikaalne mitmekesisus jms. Programm selleks on esmase 
versioonina juba olemas. Siinses uurimuses hindasid töid õpetajad, mistõttu oli hinnang eeltoodud näitajatele subjektiivne.

E-kirja kirjutasid mõlemas keeles II astme õpilased tunduvalt paremini, kusjuures vahe oli päris suur. Aga kui eesti õppkeelega koolis kirjutasid jutustava teksti võrdselt mõlema astme õpilased, siis vene koolis kirjutasid II astme õpilased veidi kehvemini kui I astme õpilased. Põhjust sellele ei ole võimalik üldise analüüsi põhjal öelda ja seegi näitab, et täpsem kirjutiste uuring on vajalik.

Sellegi analüüsi tulemusena leidis kinnitust arvamus, et õigekirjavigade arvestamisel tuleks lähtuda muuhulgas teksti pikkusest ehk arvestada õigekirjavigu näiteks ühe sõna kohta. Väide toetub leiule, et õigekeelsuse aspekt oli mõlemas keeles ja mõlemal kooliastmel kõrgem kirjaliku suhtluse ülesandes. Vahe oli ka suhteliselt suur. Kuna jutustavad tekstid olid oluliselt sõnarikkamad, siis järeldub, et õigekirjaoskuse taseme üle ei saa objektiivselt otsustada lihtsalt õigekirjavigade arvu järgi.

Silma jäi veel, et vene õpilaste tekstiloomeoskus on parem kui eesti õpilastel. Selle erinevuse põhjus vajab samuti edasisi uuringuid: kas vene õpilased loovad parema sisuga tekste kui eesti õpilased või tekkis erinevus eri hindajate kasutamisest.

Kokkuvõtteks tuleb nentida, et eesti ja vene õppekeelega koolide noorema astme õpilaste e-tasemetööde katsetuse kirjutamise osa üldiste tulemuste analüüs andis väärtuslikku informatsiooni ja suuna edasistele uuringutele.

\section{Tänusõnad}

Artikli valmimist on toetanud Euroopa Sotsiaalfondist rahastatud projekt "Kaasaegse ja uuendusliku õppevara arendamine ja kasutuselevõtt”.

\section{Kirjandus}

Bachman, Lyle F. 1990. Fundamental Considerations in Language Testing. Oxford: Oxford University Press.

Braine, George, Milio Yorozu 1998. Local area network (LAN) computers in ESL and EFL writing classes. - JALT Journal 20 (2), 47-59. 
EESTI JA VENE ÕPPEKEELEGA KOOLIÕPILASTE KIRJUTAMISOSKUS ...

Brindley, Geoff 2013. Task-based assessment. - Carol A. Chapelle (ed.). The Encyclopedia of Applied Linguistics. Blackwell Publishing Ltd. https://doi. org/10.1002/9781405198431.wbeal1141

Brown, H. Douglas 2000. Principles of Language Learning and Teaching (4th ed.). New York: Pearson Education Company.

Dahl, Karin L., Nancy Farnan 2000. Childrens's Writing: Perspectives from Research. Newark: IRA.

Durga, Satya Sri, Chandra Sekhar Rao 2018. Developing Students' Writing Skills in English: A Process Approach. - Journal for Research Scholars and Professionals of English Language Teaching 2 (6), 1-5. https://www.jrspelt.com/ wp-content/uploads/2018/05/Satya-writing-skills.pdf (22.7.2021).

Eslon, Pille, Annektarin Kaivapalu 2020. Teel sihtkeelepärase keelekasutuse poole: vene- ja soomekeelsete eesti keele õppijate kirjaliku keelekasutuse dünaamika A2- ja B1-tasemel ['Towards target-like language use: Russian and Finnish learners' dynamics of written Estonian on A2- and B1-level']. Lähivõrdlusi. Lähivertailuja 30, 57-88. https://doi.org/10.5128/LV30.01

Fulcher, Glenn, Fred Davidson 2007. Language Testing and Assessment: An Advanced Resource Book. New York: Routledge.

Giraldo, Frank 2020. Task-based language assessment: Implications for the language classroom. - GiST Education and Learning Research Journal 21, 209-224. https://doi.org/10.26817/16925777.828

Goldberg, Amie, Michael Russell, Abigail Cook 2003. The effect of computers on student writing: A meta-analysis of studies from 1992 to 2002. - Journal of Technology, Learning and Assessment 2 (1), 3-51.

Graham, Steve, Debra McKeown, Sharlene Kiuhara, Karen R. Harris 2012. A meta-analysis of writing instruction for students in the elementary grades. - Journal of Educational Psychology 104 (4), 879-896. https://doi. org/10.1037/a0029185

Harmer, Jeremy 1988. How to Teach Writing. Harlow: Longman.

Harmer, Jeremy 2004. How to Teach Writing. Harlow: Longman.

Hyland, Ken 2009. Teaching and Researching Writing. London: Longman.

Holliway, David R., Deborah McCutchen 2004. Audience perspective in young writers' composing and revising. - Linda Allal, Lucile Chanquoy, Pierre Largy (eds.). Revision Cognitive and Instructional Processes. Studies in Writing 13. Boston \& Dordrecht \& New York: Springer, 87-101. https:// doi.org/10.1007/978-94-007-1048-1_6 
Javed, Muhammad, Wu Xiao Juan, Saima Nazli 2013. A study of students' assessment in writing skills of the English language. - International Journal of Instruction 6 (2), 129-144.

Johnstone, Karla M., Hollis Ashbaugh, Terry D. Warfield 2002. Effects of repeated practice and contextual-writing experiences on college students' writing skills. - Journal of Educational Psychology 94 (2), 305-315. https://doi. org/10.1037/0022-0663.94.2.305

Kellogg, Ronald T. 2008. Training writing skills: A cognitive developmental perspective. - Journal of Writing Research 1 (1), 1-26. https://doi. org/10.17239/jowr-2008.01.01.1

Lee, Song-Eun 2011. Investigation of the Differences between L1 and L2 Writers from the Perspectives of Instructors: A Case Study of Two Secondary School Teachers. MA Thesis. Purdue University. https://www.proquest. com/docview/905311619 (22.7.2021).

McMackin, Mary C., Barbara Siegel 2002 Knowing How. Researching and Writing Nonfiction 3-8. Portland, Maine: Stenhouse Publishers.

Moskal, Barbara M. 2003. Recommendations for developing classroom performance assessments and scoring rubrics. - Practical Assessment Research \& Evaluation 8, article 14. https://doi.org/10.7275/jz85-rj16

Nation, I.S.P, John Macalister 2021. Teaching ESL/EFL Reading and Writing (2nd edition). New York: Routledge. https://doi.org/10.4324/9781003002765

Nunan, David 1991. Language Teaching Methodology: A Textbook for Teachers. Edinburgh \& Harlow: Longman.

Puksand, Helin 2019. Lugemine ['Reading']. - Gunda Tire jt. PISA 2018: Eesti tulemused. Eesti 15-aastaste õpilaste teadmised ja oskused funktsionaalses lugemises, matemaatikas ja loodusteadustes. Tallinn: Innove, 21-42.

Riley, Jeni, David Reedy 2000. Developing Writing for Different Purposes: Teaching about Genre in the Early Years. London: SAGE Publications. https:// doi.org/10.4135/9781446219515

Rivers, Wilga M. 1981. Teaching Foreign Language Skills in a Foreign Language Skills. Chicago: University of Chicago Press. https://doi.org/10.7208/ chicago/9780226518855.001.0001

Singer, Nancy Robb, Paul LeMahieu 2011. The effect of scoring order on the independence of holistic and analytic scores. - The Journal of Writing Assessment 4 (1). https://www.journalofwritingassessment.org/article. php? article $=51$

Spandel, Vicki, Richard J. Stiggins 1997. Creating Writers: Linking Writing Assessment and Instruction. New York: Longman. 
EESTI JA VENE ÕPPEKEELEGA KOOLIÕPILASTE KIRJUTAMISOSKUS ...

Zemach, Dorothy E., Lisa A. Rumisek 2005. Academic Writing. New York: MacMillan.

Tasemetööd ['Level exams']. Haridus- ja Noorteamet. https://harno.ee/tasemetood\#materjalid (15.5.2021).

Templeton, Shane 1997. Teaching the Integrated Language Arts. USA: Houghton Mifflin Company.

Tierney, Robin, Marielle Simon 2004. What's still wrong with rubrics: Focusing on the consistency of performance criteria across scale levels. - Practical Assessment, Research \& Evaluation 9, article 2. https://doi.org/10.7275/ jtvt-wg68

Urquhart, Vicki, Monette McIver 2005. Teaching Writing in Content Areas. USA: ASCD.

Uusen, Anne 2006. Põhikooli I ja II astme õpilaste kirjutamisoskus ['Writing Skills of 1st and 2nd Stage Students']. Tallinna Ülikooli sotsiaalteaduste dissertatsioonid 19. Tallinn: Tallinna Ülikooli Kirjastus.

Uusen, Anne, Helin Puksand 2021. Põhikooli I ja II astme õpilased arvutiga kirjutajatena: kas pikemaaegsem arvuti kasutamise kogemus tagab paremad tulemused tekstiloomes? ['1st and 2nd stage students of basic school as writers by computer: Does a longer-term computer use experience guarantee better results in text creation?'] - Emakeele Seltsi aastaraamat 66, 310-326. https://doi.org/10.3176/esa66.13

Wang, Zhanming M. 2014. Review of the influence of L1 in L2. - Acquisition Studies in Literature and Language 9 (2), 57-60. https://doi.org/10.3968/5721

Writing Assessment: A Position Statement. National Council of Teachers of English, 2014. https://ncte.org/statement/writingassessment/ (22.7.2021).

\section{Anne Uusen}

Tallinna Ülikooli haridusteaduste instituut

Uus-Sadama 5, 10120 Tallinn, Estonia

uusen@tlu.ee

\section{Helin Puksand}

Tallinna Ülikooli haridusteaduste instituut

Uus-Sadama 5, 10120 Tallinn, Estonia

helin.puksand@tlu.ee 


\title{
Writing skills of Estonian and Russian language speaking school students based on the results of the mother tongue standard-determining e-tests
}

\author{
ANNE UUSEN, HELIN PUKSAND \\ Tallinn University
}

The Covid-19 pandemic has significantly changed something in society and at school. Communication is increasingly taking place in a hybrid form, and therefore the ability to communicate one's thoughts in a comprehensible way to a communication partner in writing, i.e., relevant writing skills, is becoming more and more important.

Research has shown that mother tongue skills, and more specifically the ability to write in the mother tongue, provide input and help to acquire a second language and / or the language of the learner. Consequently, when preparing for the full transition to Estonian-language education, it is important to know how the writing skills of current first and second stage students of Estonian and Russian speaking basic school are similar and different. The opportunity to compare the writing skills of the students of two school types a little more precisely arose from the basis of the general results of the writing part of the e-tests tested in October 2019 in the 1st and 2nd level of basic school.

The definition of the construct to be assessed was based on the definitions of several authors, which can be summarized as complicated and complex activity of creating high-quality writing, which consists of different stages. To assess writing skills, it must be established in advance how, what and for what purpose will be assessed. As in standard-determining tests it is possible to assess the result of writing or text, the assessment guide was based on a product approach and, more narrowly, on an analytical assessment model. At both school levels, there were two writing tasks in Estonian and Russian: the task of writing communication and writing the narrative text. The analysis showed that the tasks were generally reliable and measured what was expected. The reliability of the tasks of writing a narrative text was rather low in the first stage test of Estonian 
WRITING SKILLS OF ESTONIAN AND RUSSIAN LANGUAGE SPEAKING ..

and in both stage tests in Russian. This shows that as many aspects as possible should be assessed at least in the narrative text. In both text creation tasks, three aspects were assessed: text creation or content, orthography, and digital writing skills, and in the written communication task, also the ability of written communication.

The analysis of the results of Estonian and Russian speaking school students concluded that it was somewhat surprising that the average results of both the e-mail and the narrative text were better of Russian school students in both stages. Surprisingly because of this that, for example, in the PISA surveys, in reading skills Russian school students performed worse (Puksand 2019). As the texts were evaluated by the teachers and not by the computer, this result can be justified on the one hand by the fact that the human evaluation is always influenced by subjective factors, no matter how unambiguous the evaluation guide is. On the other hand, this makes possible to believe more confidently that for the transition to Estonian-language education, first and second stage students of Russian-speaking basic schools will have at least a satisfactory level input of writing skills.

The e-mail was written much better by the second stage students in both languages, with a big difference, but while the narrative text was written equally by students of both grade in Estonian schools, then in Russian school, second stage students wrote slightly worse than first stage students.

As a result of analysis described in the article, the opinion was confirmed that the calculation of spelling errors should be based on the length of the text. It was also noticeable that the text creation skills of Russian students are better than those of Estonian students. The reason for this difference also needs further research. In conclusion, it should be noted that the analysis of the general results of the writing part of low stake e-test of first and second stage students in Estonian and Russian language speaking schools provided valuable information and gave direction for further research.

Keywords: creation of written text; components of writing; digital writing skills; analytical assessment; text-based assessment; Estonian; Russian 